\title{
Digenean trematodes-marine mollusc relationships: a stable isotope study
}

\author{
S. Y. Dubois ${ }^{1, *}$, N. Savoye ${ }^{1}$, P.-G. Sauriau ${ }^{2}$, I. Billy ${ }^{3}$, P. Martinez ${ }^{3}$, X. de Montaudouin ${ }^{1}$ \\ ${ }^{1}$ Université de Bordeaux, CNRS UMR 5805, EPOC, Station Marine d'Arcachon, 2 rue du Pr. Jolyet, 33120 Arcachon, France \\ ${ }^{2}$ Université de La Rochelle, CNRS UMR 6250, LIENSs, 2 rue Olympe de Gouges, 17000 La Rochelle, France \\ ${ }^{3}$ Université de Bordeaux, CNRS UMR 5805, EPOC, Avenue des Facultés, 33405 Talence cedex, France
}

\begin{abstract}
The stable carbon and nitrogen isotopic composition of digenean trematode parasites and their marine mollusc hosts was investigated to describe the potential influence of parasites on their host and its different tissues, and to obtain further insight into their trophic relationships. Four parasite-host systems were studied: Labratrema minimus-Cerastoderma edule, Monorchis parvusC. edule, Lepocreadiidae parasites-Nassarius reticulatus and Zoogonidae parasites-N. reticulatus. Among the 4 sampling occasions reported here and corresponding to the 4 parasite-host systems, isotopic shifts from pathologic (i.e. linked to disturbances in host metabolism) and mass-balance (i.e. linked to significant differences between host and parasite isotopic signatures) origins were observed only once. Both corresponded to $\delta^{13} \mathrm{C}$ measurements of the L. minimus-C. edule system when the infestation load (percentage parasite dry weight compared to total flesh dry weight) was highest (9 to $25 \%$, mean $=16 \%$ ) over the sampling period. Overall, measurements indicate that digenean trematode parasitism induced low or no shifts in isotopic signatures of $C$. edule and $N$. reticulatus tissues. The 2 endoparasites $L$. minimus and $M$. parvus appeared to be slightly depleted in ${ }^{13} \mathrm{C}$ compared to C. edule digestive gland and gonads, which were the most parasitized tissues. In contrast, no fractionation or low ${ }^{15} \mathrm{~N}$ trophic enrichments occurred in the parasites. These results highly contrast with the classical trophic enrichment reported in prey-predator systems but are in agreement with the scarce literature regarding other parasite-host systems. Our results indicate that (1) digenean trematodes mainly feed on digestive glands (the cockle tissue with which they are mainly associated) with a possible slight preference for lipids, and (2) fractionation due to parasite metabolism should be low due to abbreviated metabolic pathways and/or slight loss of materials through excretion, tegument diffusion and respiration.
\end{abstract}

KEY WORDS: Parasitism $\cdot \mathrm{C}$ and $\mathrm{N}$ stable isotopes $\cdot$ Marine molluscs $\cdot$ Digenean trematodes Resale or republication not permitted without written consent of the publisher

\section{INTRODUCTION}

In the past few decades, stable isotope analysis has become widely used in ecological studies, notably in trophic web studies (e.g. Peterson \& Fry 1987, Rau et al. 1991, Gannes et al. 1997, Paulet et al. 2006). Carbon and nitrogen stable isotopes provide medium- to longterm information about food assimilated by organisms, in contrast to gut contents, which only provide a snapshot view. Thus, stable isotope ratios represent an efficient tool for trophic web studies since they can be used as natural tracers of energy transfers. Isotopic composition of an organism reflects the isotopic composition of its food sources, plus a few permil. It is usually considered that a consumer is enriched by $1 \%$ in $\delta^{13} \mathrm{C}$ and 3 to $4 \%$ in $\delta^{15} \mathrm{~N}$ with respect to its food (DeNiro \& Epstein 1978, 1981, Hobson \& Welch 1992, Post 2002), even if large scatter exists between species (e.g. Peterson \& Fry 1987, Vander Zanden \& Rasmussen 2001, Yokoyama et al. 2005). This trophic enrichment is linked to the respiratory metabolism for the carbon isotope and the excretory metabolism for the nitrogen isotope: ${ }^{12} \mathrm{C}$ is the preferentially respired C-isotope whereas ${ }^{14} \mathrm{~N}$ is the preferentially excreted 
$\mathrm{N}$-isotope. This leads to the relative increase of ${ }^{13} \mathrm{C}$ and ${ }^{15} \mathrm{~N}$ in consumers relative to their food sources (e.g. Checkley \& Entzeroth 1985).

Parasitism is an antagonistic relationship in which an organism, i.e. the parasite, benefits at the expense of another organism, i.e. the host (Combes 1995). Thus, parasite-host relationships can be seen as a special case of predator-prey relationships. In that context, one can expect that the usual isotopic trophic enrichments observed between predators and their prey stand for parasite-host relationships. However, there are 2 essential differences between these 2 relationships: (1) the interaction period between parasite and host exists for a longer period of time (a few days to a few years) than does that of predator and prey (a few seconds to a few minutes) and (2) the relationship between parasites and hosts is relatively inconspicuous, because parasites are generally of small size and are not, or are hardly, visible from outside (Combes 1995). Parasites are ubiquitous in littoral environments (Lauckner 1984, Thomas et al. 1997), and their relationships with hosts cover different aspects and degrees of interaction, i.e. from ectoparasites, which are external parasites living at the surface of host teguments, to endoparasites, which live nestled in host tissues. Endoparasites can be located in alimentary canals as well as interwoven within host tissues depending on species and/or stages (Lauckner 1983). As endoparasites, digenean trematodes exhibit a heteroxenous life cycle, i.e. they need several host species. The parasite sexual reproduction takes place in a vertebrate host (= final host) and leads to the production of eggs that are released in water with host faeces. Eggs evolve to miracidium larvae which infest the first intermediate host (always a mollusc). Miracidium larvae evolve in germinative bags (mother-sporocysts) in which other germinative structures grow up. They can either have a mouth and a gut (rediae), or be gutless (sporocysts). Sporocysts and rediae have, however, different trophic behaviours: sporocysts use dissolved organic matter as an energy source, while rediae are reported to eat host tissue directly. Both forms are very deleterious for their hosts because of their invasive nature, especially in the gonad (Jensen \& Mouritsen 1992, Thieltges 2006). They can lead to castration as reported by Deltreil \& His (1970) for the cockle Cerastoderma edule, in which prevalence of digenean trematode is usually lower than $5 \%$ (Desclaux et al. 2002), but can exceed 50\% and lead to mass mortality (Thieltges 2006). The penultimate step in the parasite life cycle is the emission (by sporocysts and/or rediae) of swimming larvae (cercariae) that infect a second intermediate host whose populations generally display high parasite prevalence (de Montaudouin et al. in press). The cycle is completed when the second intermediate host is preyed upon by the final host.

A priori, both pathology and mass-balance related processes may induce shifts in stable isotope ratios between healthy and parasitized individuals. First, as exemplified by digenean trematodes parasiting the cockle Cerastoderma edule, parasites may disturb the metabolism of cockles and especially through their digestive gland, one of the main impacted organs (James \& Bowers 1967, Lauckner 1983). This disturbance results in biochemical and histological changes in tissue composition, as exemplified by the increase of neutral lipids and fatty acids and the decrease of glucose and glycogen content (Lauckner 1983). Such a pathologic effect would induce a shift in the isotopic signature in one or several organ(s) and, consequently, of entire individuals since different biochemical compounds are known to have different stable isotope signatures (DeNiro \& Epstein 1977, Fantle et al. 1999, Pakhomov et al. 2004, Bodin et al. 2007). This shift is referred to as 'pathologic' shift.

Secondly, stable isotope signatures of a parasitehost system could be shifted if (1) the parasite exhibits an isotopic signature that is very different from that of the host, (2) healthy and parasitized (after parasite removal) individuals exhibit similar isotopic signatures, and (3) the mass of the parasite within the parasite-host system is large enough. This shift is referred to as 'mass-balance' shift, and has been reported by Doi et al. (2008).

To date, only a few studies have investigated parasite-host relationships using $\mathrm{C}$ and $\mathrm{N}$ stable isotopes. They have reported that the 'regular' isotopic enrichment of $1 \%$ for $\delta^{13} \mathrm{C}$ and 3 to $4 \%$ for $\delta^{15} \mathrm{~N}$ is not the rule (Iken et al. 2001, Pinnegar et al. 2001, Deudero et al. 2002, Parmentier \& Das 2004, Power \& Klein 2004). However, these studies have examined parasite-host systems with physiological links much weaker than in digenean trematode-mollusc systems and have involved species in other phylogenetic groups than trematodes. The present study investigates the digenean trematode-mollusc host relationship using $\mathrm{C}$ and $\mathrm{N}$ stable isotopes. Both potential pathologic and mass-balance shifts were investigated by comparing the istotopic signature of healthy vs. parasitized tissues and individuals on the one hand and healthy individuals vs. parasites and parasitehost systems on the other hand. Our specific aims were to investigate: (1) the effect of sporocyst stage of digenean trematodes on the bivalve mollusc Cerastoderma edule (cockle) and the gastropod mollusc Nassarius reticulatus (dogwhelk) isotopic signatures, and (2) the trophic relationships between hosts and parasites. 


\section{MATERIALS AND METHODS}

Sampling strategy. Four parasite-host systems were studied: 2 digenean trematode parasites Labratrema minimus and Monorchis parvus relating to the cockle Cerastoderma edule, and 2 digenean trematode parasites Lepocreadiidae and Zoogonidae relating to the dogwhelk Nassarius reticulatus (see Table 1). Only Lepocreadiidae have rediae in their first intermediate host, whereas the other species cited above have sporocysts (Maillard 1976, Russell-Pinto et al. 2006). Samples came from Banc d'Arguin and Pereire located at the entrance of Arcachon Bay, which is a $180 \mathrm{~km}^{2}$ semi-closed macrotidal lagoon along the southwest Atlantic coast of France. Cockles were sampled by ploughing the sand with fingers on a intertidal site at Banc d'Arguin on 3 dates, 24 January, 19 February and 5 April 2007, which corresponded to different stages of parasite infestation (e.g. from $2 \%$ of the total cockle flesh weight in January to $25 \%$ in April, see Table 1). At each sampling occasion, 500 adult cockles were collected to balance the low expected prevalence of trematodes (Desclaux et al. 2002). Dogwhelks were sampled on a subtidal site at Pereire on 14 March 2007 (see Table 1). About 200 dogwhelks were collected with small cages filled with crushed slipper limpet Crepidula fornicata flesh as bait (Bachelet et al. 2004).

Five healthy and 5 parasitized individuals were analysed at each sampling occasion. However, since gametogenesis in cockles was already advanced in January, the potential influence of sex on the cockle isotopic signatures was investigated. Five males and 5 females were selected for $\delta^{15} \mathrm{~N}$ and $\delta^{13} \mathrm{C}$ analyses in January. Since males and females exhibited similar isotopic signatures (see 'Results'), sex was not determined for the study of the parasite-host system. Five organs were dissected from each cockle: the foot, the 2 adductor muscles, the mantle, the gills and the 'rest' (mainly the digestive gland and gonad, DGG). Since feet, gills and mantle exhibited similar $\delta^{15} \mathrm{~N}$ and $\delta^{13} \mathrm{C}$ signatures, these 3 organs were combined in a unique sample (FGM). Most of the parasites from each sample were extracted, although it was impossible to remove all sporocysts, which are entangled in the tissues.

Four tissues were separated from each dogwhelk: the muscular section, the digestive gland, the gonad and the operculum. However, it was not possible to remove parasites from their infected tissues.

Sample processing. In the laboratory, individuals were placed in filtered seawater $(0.5 \mu \mathrm{m})$ for $24 \mathrm{~h}$ to drain the organisms out of their gut contents. Total shell lengths (bivalve) and total shell heights (gastropod) were measured (in $\mathrm{mm}$ ). Flesh was extracted and squeezed between 2 glass slides to detect parasite presence under binoculars. The different organs were dissected and parasites extracted from cockle tissues as previously mentioned. Tissue samples were placed into precombusted and decarbonated glass vials. Samples were then frozen and stored at $-80^{\circ} \mathrm{C}$ before further processing. A few days before analysis, samples were freeze-dried and weighed to determine dry weight. Finally, samples were ground into a fine and homogeneous powder.

Isotopic analysis. Powder samples (ca. 1 to $1.5 \mathrm{mg}$ ) were weighed into tin cups without further processing for $\delta^{15} \mathrm{~N}$ analysis. For $\delta^{13} \mathrm{C}$ analysis, 0.6 to $0.8 \mathrm{mg}$ powder was weighed into silver cups. Fifty $\mu \mathrm{l}$ of $1.2 \mathrm{~N} \mathrm{HCl}$ was added into the cup in order to remove carbonates. The cup containing the wet sample was dried overnight in an oven at $60^{\circ} \mathrm{C}$. Thus $\delta^{13} \mathrm{C}$ and $\delta^{15} \mathrm{~N}$ analysis were measured in 2 distinct subsamples. Subsamples were analysed for $\mathrm{C}$ and $\mathrm{N}$ contents and stable isotope ratios using an elemental analyser (EA, NC2500, Carlo Erba) coupled to an isotope ratio mass spectrometer (IRMS, Isoprime, GV Instruments). Daily drift was monitored using a homemade standard (cockle foot) and, if present, data were corrected. EA and IRMS instruments were calibrated using acetanilide and reference material (IAEA-N1, IAEA-N2 and USGS24), respectively.

All isotopic data are given in the conventional delta notation in units of parts per thousand $(\%)$ :

$\delta^{13} \mathrm{C}_{\text {sample }}$ or $\delta^{15} \mathrm{~N}_{\text {sample }}=\left(\mathrm{R}_{\text {sample }} / \mathrm{R}_{\text {reference }}-1\right) \times 1000$

where $\mathrm{R}={ }^{13} \mathrm{C} /{ }^{12} \mathrm{C}$ or ${ }^{15} \mathrm{~N} /{ }^{14} \mathrm{~N}$, and the reference is Pee Dee Belemnite for $\delta^{13} \mathrm{C}$ and atmospheric nitrogen for $\delta^{15} \mathrm{~N}$. Analysis uncertainty is given by the median of 9 SD of standard (homemade cockle foot standard) replicates: $0.14 \%$ for $\delta^{13} \mathrm{C}$ and $0.10 \%$ for $\delta^{15} \mathrm{~N}$.

The isotopic value of integral individuals was calculated as following:

$$
\delta_{\text {individual }}=\frac{\sum\left(q_{\text {tissue }} \times \delta_{\text {tissue }}\right)}{\sum\left(q_{\text {tissue }}\right)}
$$

where $\delta$ is $\delta^{15} \mathrm{~N}$ or $\delta^{13} \mathrm{C}$ and $\mathrm{q}_{\text {tissue }}$ is the $\mathrm{C}$ or $\mathrm{N}$ weight in tissue.

Statistical analyses. Differences in stable isotope ratios between species and organs were tested by 1 -way ANOVA with replication when variance was homogeneous, with a significance at $\mathrm{p}<0.05$. When the variance was heterogeneous, 1-way ANOVA was replaced by the non-parametric Mann-Whitney $U$-test. Differences between entire healthy cockles, entire diseased cockles and parasites were tested by 1-way ANOVA or by a Kruskal-Wallis test when variances were not homogenous. The a posteriori Tukey's HSD test was used when ANOVA results were significant. All statistical analyses were performed with STATISTICA 7.1 (StatSoft). 


\section{RESULTS}

\section{Male vs. female stable isotope ratios}

No significant difference in isotopic ratio was recorded between male and female individual cockles for $\delta^{15} \mathrm{~N}$ (1-way ANOVA, $\mathrm{p}=0.56$, mean $=7.7 \pm$ $0.3 \%$ and $7.8 \pm 0.4 \%$ o for males and females, respectively) or $\delta^{13} \mathrm{C}$ (Mann-Whitney $U$-test, $\mathrm{p}=0.92$, mean $=-17.6 \pm 0.3 \%$ and $-17.6 \pm 0.04 \%$ for males and females, respectively). Consequently, male and female cockles were not distinguished for further analysis. As a result, the potential influence of sex on the stable isotopic signatures of dogwhelks was not investigated and assumed to be negligible.

\section{Parasite-cockle systems}

Mean isotopic signatures of healthy and parasitized entire cockles ranged between 6.8 and $7.9 \%$ or for $\delta^{15} \mathrm{~N}$ and between -17.7 and $-16.6 \%$ for $\delta^{13} \mathrm{C}$ (Figs. $1 \& 2$ ). For each sampling date, parasites (Labratrema minimus vs. Monorchis parvus) and parasite status (i.e. healthy vs. parasitized), mean $\delta^{15} \mathrm{~N}$ and $\delta^{13} \mathrm{C}$ values were lower for DGG (1-way ANOVA, p $<0.25 ; \delta^{15} \mathrm{~N}$ : 6.3 to $7.6 \%$;
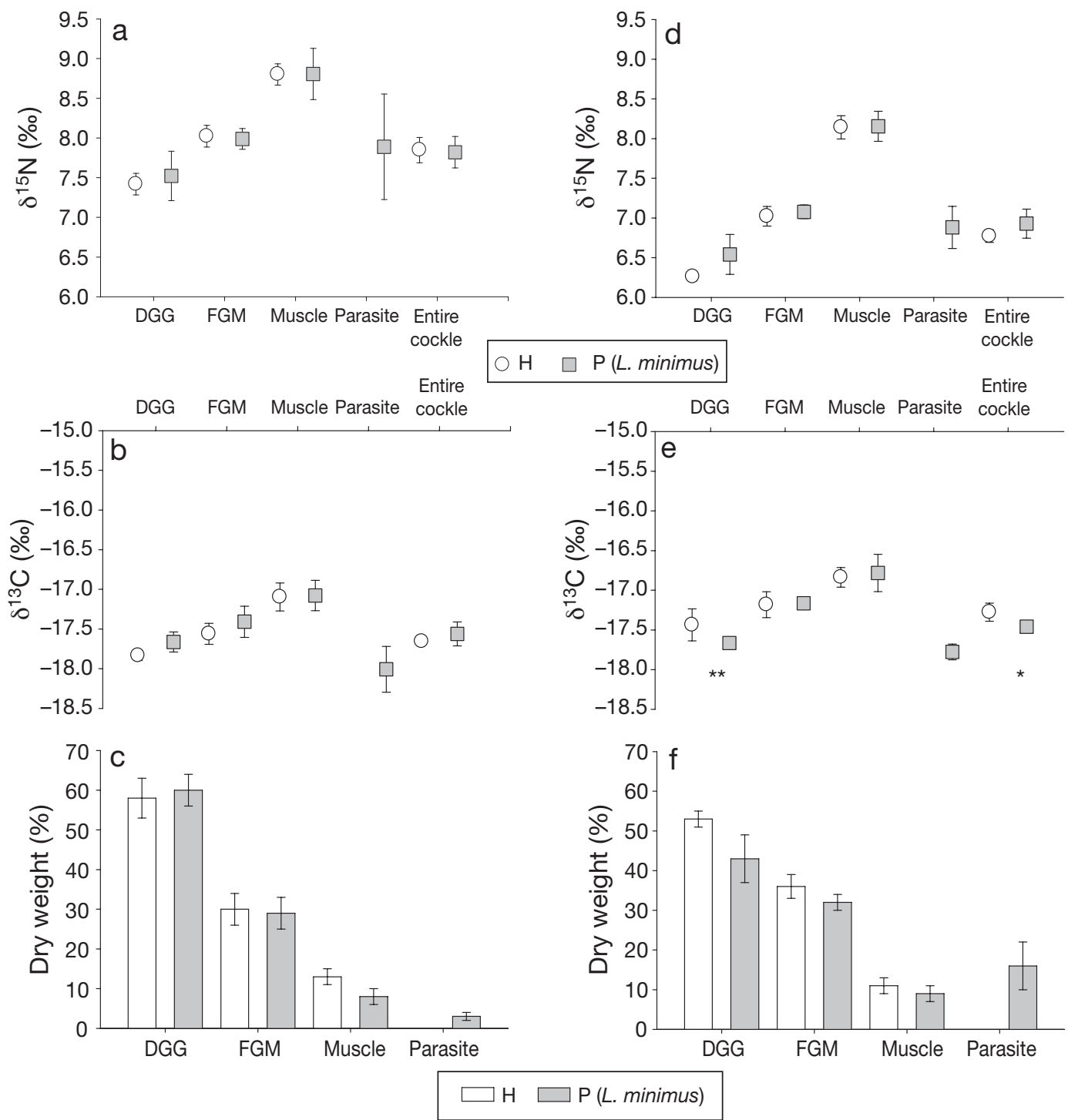

Fig. 1. Cerastoderma edule and Labratrema minimus. Mean $\delta^{15} \mathrm{~N}(\mathrm{a}, \mathrm{d})$ and $\delta^{13} \mathrm{C}(\mathrm{b}, \mathrm{e})$ of healthy $(\mathrm{H})$ and parasitized $(\mathrm{P})$ cockle organs and parasites. Relative contribution (c,f) of each organ and parasite to the dry weight of entire cockles or parasite-host systems. Samples were collected on 24 January $(\mathrm{a}-\mathrm{c})$ and 4 May 2007 (d-f). Error bars are 1 SD $(\mathrm{n}=5)$. Asterisks indicate significant difference between healthy and parasitized organs. ${ }^{*}: \mathrm{p}<0.05{ }^{* *}: \mathrm{p}<0.01$. DGG: Digestive gland and gonad; FGM: foot, gills and mantle 
$\delta^{13} \mathrm{C}:-17.8$ to $-16.9 \%$ ) than for FGM $\left(\mathrm{p}<0.44 ; \delta^{15} \mathrm{~N}: 7.0\right.$ to $8.0 \%$; $\delta^{13} \mathrm{C}:-17.6$ to $-16.5 \%$ ) and than for muscle $(\mathrm{p}<$ $0.44 ; \delta^{15} \mathrm{~N}$ : 8.1 to $8.8 \%$; $\delta^{13} \mathrm{C}:-17.1$ to $-16.0 \%$ o).

\section{Labratrema minimus-cockle}

Labratrema minimus prevalence in cockles increased from 1 to $17 \%$ between January and April (Table 1). The parasite was mainly located within and around the DGG.

Regardless of sampling date, FGM and muscle masses accounted for 24 to $35 \%$ and 5 to $12 \%$ of the cockle dry weight, respectively (Fig. 1C,f). In contrast, temporal changes were evident for the other tissues: the contribution of DGG to the cockle dry weight decreased from $60 \%$ (range $=55$ to $65 \%$ ) to $43 \%$ (35 to $49 \%)$, whereas the parasite contribution increased (Fig. 1c,f) from 3\% (2 to $5 \%$ ) to $16 \%$ (9 to $25 \%$ ) between January and April.

Comparison between healthy and parasitized cockles sampled at both dates revealed no significant difference in $\delta^{15} \mathrm{~N}$ between organs $(p=0.60)$ or between individuals of healthy and parasitized cockles ( $\mathrm{p}=$ 0.38). There was no significant difference between parasite and healthy DGG in January ( $\mathrm{p}=0.42)$, con-
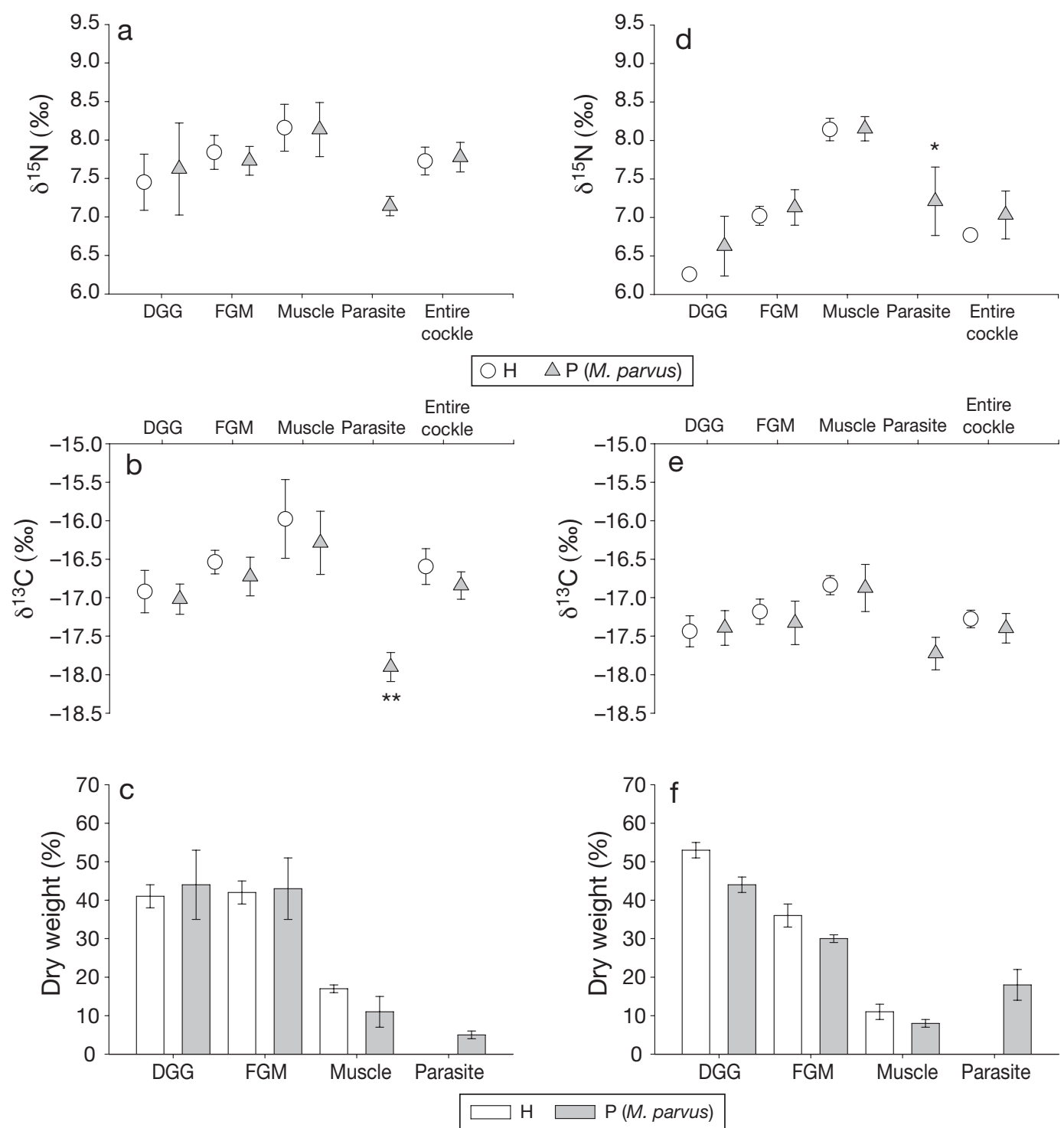

Fig. 2. Cerastoderma edule and Monorchis parvus. Mean $\delta^{15} \mathrm{~N}(\mathrm{a}, \mathrm{d})$ and $\delta^{13} \mathrm{C}(\mathrm{b}, \mathrm{e})$ of healthy $(\mathrm{H})$ and parasitized $(\mathrm{P})$ cockle organs and parasites. Relative contribution $(\mathrm{c}, \mathrm{f})$ of each organ and parasite to the dry weight of entire cockles or parasite-host systems. Samples were collected on 19 February (a-c) and 4 May 2007 (d-f). Error bars are 1 SD (n = 5). Asterisks indicate significant difference between healthy and parasitized organs. ${ }^{*}: \mathrm{p}<0.05_{i}{ }^{* *}: \mathrm{p}<0.01$. DGG: Digestive gland and gonad; FGM: foot, gills and mantle 
Table 1. Parasite-host systems studied. Parasite and host species, sampling dates, parasite dry weight (DW) (\% parasite DW compared to total flesh DW) and host shell size (Cerastoderma edule length or Nassarius reticulatus height)

\begin{tabular}{|llccc|}
\hline Parasite & \multicolumn{1}{c}{ Host } & Sampling date & Parasite DW (\%) & Shell size (mm) \\
\hline Labratrema minimus & Cerastoderma edule & 24 Jan 07 & 2 to 5\% & 31 to 39 \\
Labratrema minimus & Cerastoderma edule & 05 Apr 07 & 9 to 25\% & 32 to 40 \\
Monorchis parvus & Cerastoderma edule & 19 Feb 07 & 4 to 6\% & 22 to 28 \\
Monorchis parvus & Cerastoderma edule & 05 Apr 07 & 14 to 22\% & 32 to 36 \\
Lepocreadiidae & Nassarius reticulatus & 14 Mar 07 & unknown & 19 to 27 \\
Zoogonidae & Nassarius reticulatus & 14 Mar 07 & unknown & 17 to 22 \\
\hline
\end{tabular}

trary to April, when parasite was significantly ( $\mathrm{p}=$ 0.008 ) enriched by $0.6 \%$ with respect to DGG (Table 2 , Fig. 1a,d, see Fig. 4a).

These features were also valid for $\delta^{13} \mathrm{C}$ signatures in January but not in April; there was a significant difference between healthy and parasitized cockles in April for DGG ( $p=0.008)$ and between individuals when the percentage of infestation reached, on average, $16 \%$ $(p=0.14)$ (Table 2, Fig. 1b,e,f). However, these $\delta^{13} \mathrm{C}$ differences were as low as $0.2 \%$. A difference in $\delta^{13} \mathrm{C}$ signature was observed between Labratrema minimus and healthy DGG: parasites were depleted in ${ }^{13} \mathrm{C}(-0.2$ and $-0.3 \%$ in January and April, respectively), however this depletion was only significant in April ( $\mathrm{p}=$ 0.01) (Table 2, Fig. 1b,e see Fig. 4b).

\section{Monorchis parvus-cockle}

Parasites were mainly located within and around the DGG but also occurred within and around the mantle and the gills.

DGG and muscle masses, respectively, accounted for $44 \%$ (range $=34$ to $56 \%$ ) and for 7 to $17 \%$ of the cockle dry weight in February and April. The contribution of FGM to the cockle dry weight decreased with time from $43 \%$ (32 to $52 \%$ ) to $30 \%$ (28 to $32 \%$ ), whereas the parasite contribution increased from $5 \%$ (4 to $6 \%$ ) to $18 \%$ (14 to $22 \%$ ) (Fig. 2c,f).
The comparison between healthy and parasitized cockles sampled at both dates revealed no significant difference in $\delta^{15} \mathrm{~N}$ between organs $(\mathrm{p}=0.25)$ or between individual healthy and parasitized cockles ( $\mathrm{p}=$ 0.11). There was, however, a difference between Monorchis parvus and healthy DGG of cockles: the parasite was not significantly depleted in ${ }^{15} \mathrm{~N}$ ( $\mathrm{p}=$ $0.25,-0.3 \%$ ) in February and was significantly enriched $(p=0.016,+1.0 \%$ ) in April (Table 2, Fig. 2a,d, see Fig. 4a).

Similar trends were recorded for $\delta^{13} \mathrm{C}$ signatures: there was no significant difference between organs ( $p=0.29$ ) or entire individuals $(p=0.053)$ of healthy vs. parasitized cockles, whereas Monorchis parvus was significantly ( $\mathrm{p}=0.008,-1.0 \%$ ) and not significantly $(\mathrm{p}=0.08,-0.3 \%$ ) depleted in February and April, respectively, with respect to healthy DGG (Table 2, Fig. 2b,e, see Fig. 4b).

Some of the above differences between healthy and parasitized systems or tissues were almost significant $(p=0.053$ and $p=0.08)$. However, the differences were very low (from 0.12 to $0.3 \%$ ) compared to spatial and temporal variability of $\delta^{13} \mathrm{C}$, and were close to the usual analytical uncertainty $(0.2 \%)$. Thus, if these differences were significant, our conclusions would still stand. Such low, but significant, differences were recorded for the Labratrema minimus-cockle system and the Monorchis parvus-cockle system (for $\delta^{15} \mathrm{~N}$ ) and are discussed below (see 'Discussion').

Table 2. Cerastoderma edule, Labratrema minimus and Monorchis parvus. Comparison of N and C stable isotopic values in digestive gland and gonad (DGG) of healthy and parasitized C. edule and of parasites L. minimus and M. parvus. P: parasite; HDGG: DGG of healthy cockle; PDGG: DGG of parasitized cockle; NS: not significant ( $p>0.05)$

\begin{tabular}{|c|c|c|c|c|c|}
\hline \multirow{2}{*}{ Parasite } & \multirow{2}{*}{$\begin{array}{l}\text { Sampling } \\
\text { date }\end{array}$} & \multicolumn{2}{|r|}{$-\delta^{15} \mathrm{~N}$} & \multirow[b]{2}{*}{ p-value } & \multirow{2}{*}{ 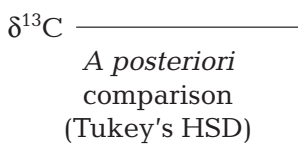 } \\
\hline & & $\mathrm{p}$-value & $\begin{array}{c}\text { A posteriori } \\
\text { comparison } \\
\text { (Tukey's HSD) }\end{array}$ & & \\
\hline Labratrema minimus & $\begin{array}{l}24 \text { Jan } 07 \\
5 \text { Apr } 07\end{array}$ & $\begin{array}{c}\mathrm{NS}(p=0.69) \\
p<0.01\end{array}$ & $\mathrm{P}>[\mathrm{PDGG} \approx \mathrm{HDGG}$ & $\begin{array}{c}\mathrm{NS}(\mathrm{p}=0.08) \\
\mathrm{p}<0.01\end{array}$ & $\stackrel{-}{\mathrm{P}}<\mathrm{PDGG}<\mathrm{HDG}$ \\
\hline Monorchis parvus & $\begin{array}{l}19 \text { Feb } 07 \\
5 \text { Apr } 07\end{array}$ & $\begin{array}{c}\mathrm{NS}(p=0.47) \\
p<0.05\end{array}$ & $\mathrm{P}>[\mathrm{PDGG} \approx \mathrm{HDGG}$ & $\begin{array}{c}\mathrm{p}<0.05 \\
\mathrm{NS}(\mathrm{p}=0.12)\end{array}$ & $\mathrm{P}<[\mathrm{PDGG} \approx \mathrm{HDGG}]$ \\
\hline
\end{tabular}




\section{Dogwhelk-parasite systems}

Dogwhelks were sampled in March 2007, and healthy individuals were compared with those parasitized by Lepocreadiidae or Zoogonidae trematodes. In both cases, muscular section, gonad, digestive gland and operculum dry weight contributed ca. $55 \%, 26 \%$, ca. $19 \%$ and 1 to $2 \%$ of the dogwhelk dry weight, respectively (Fig. 3c,f). Most of the parasites were located in the gonad and the digestive gland.

The mean isotopic signatures of healthy and parasitized dogwhelks ranged between 10.8 and $11.0 \%$ or $\delta^{15} \mathrm{~N}$, and between -16.2 and $-15.8 \%$ for $\delta^{13} \mathrm{C}$ in both parasite species (Fig. 3). No significant difference in $\delta^{15} \mathrm{~N}$ and $\delta^{13} \mathrm{C}$ values of individuals or organs was recorded between healthy and parasitized dogwhelks (1-way ANOVA, $p=0.94$ for $\delta^{15} \mathrm{~N}, \mathrm{p}=0.29$ for $\delta^{13} \mathrm{C}$ ).
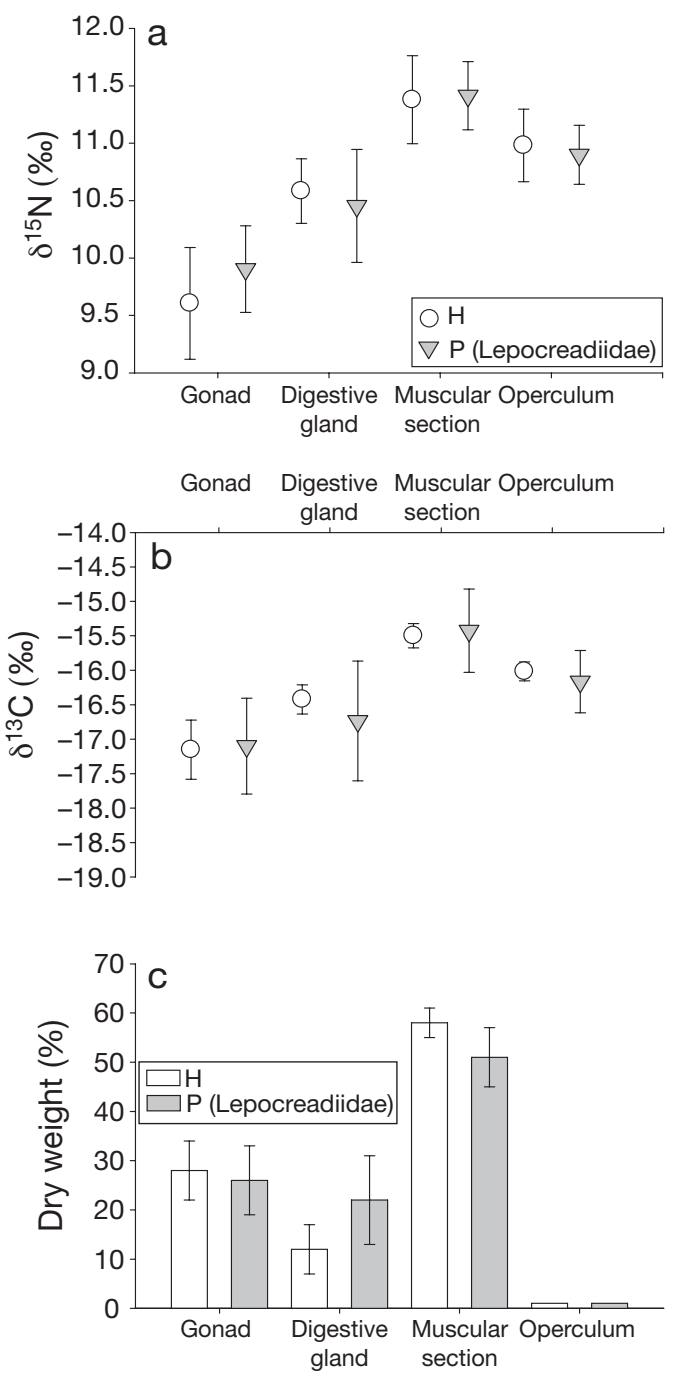

However, in all cases (i.e. healthy vs. parasitized, Lepocreadiidae vs. Zoogonidae) the mean $\delta^{15} \mathrm{~N}$ and $\delta^{13} \mathrm{C}$ values were lower for gonads $\left(\mathrm{p}<0.004 ; 9.6 \% \times \delta^{15} \mathrm{~N} \leq\right.$ $10.2 \%$; $-17.2 \% \leq \delta^{13} \mathrm{C} \leq-16.4 \%$ o) than for both digestive glands $\left(\mathrm{p}<0.004 ; 10.2 \%\right.$ o $\leq \delta^{15} \mathrm{~N} \leq 10.6 \%$; $-16.7 \%$ o $\leq \delta^{13} \mathrm{C} \leq-16.3 \%$ o) and muscular sections ( $<<0.003$; $11.4 \% \leq \delta^{15} \mathrm{~N} \leq 11.4 \%$; $-15.5 \%$ o $\leq \delta^{13} \mathrm{C} \leq-15.2 \%$ ).

\section{DISCUSSION}

\section{Digenean trematode parasitism induces low or no isotopic shifts}

Our analyses showed that the presence of parasites (Labratrema minimus, Monorchis parvus, Zoogonidae with sporocysts only, Lepocreadiidae with sporocysts
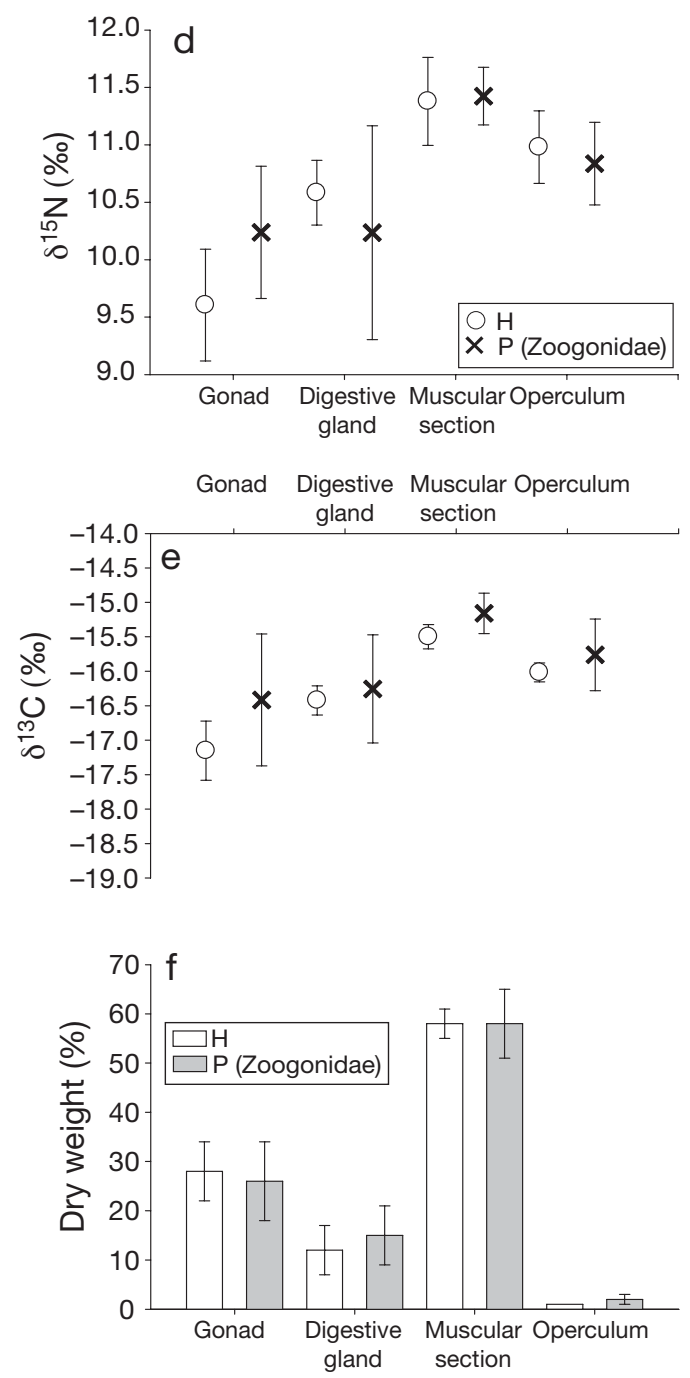

Fig. 3. Nassarius reticulatus, Lepocreadiidae and Zoogonidae. Mean $\delta^{15} \mathrm{~N}(\mathrm{a}, \mathrm{d})$ and $\delta^{13} \mathrm{C}(\mathrm{b}, \mathrm{e})$ of healthy $(\mathrm{H})$ and parasitized $(\mathrm{P})$ dogwhelk organs and relative contribution $(\mathrm{c}, \mathrm{f})$ of each organ to the dry weight of healthy and parasitized dogwhelks. Samples were collected on 14 March 2007. Error bars are 1 SD $(n=5)$ 
and rediae) in cockles Cerastoderma edule and dogwhelks Nassarius reticulatus had little or no influence on the $\mathrm{C}$ and $\mathrm{N}$ stable isotope signatures of the parasite-host systems (Figs. 1, 2 \& 3). When the determination of the isotopic signature of the parasite was not possible (i.e. for parasite-dogwhelk systems), it was assumed that one shift (pathologic or mass-balance) did not balance the other in the parasite-host system isotopic signature. Among the 4 parasite-host systems sampled on several occasions (Table 1), only one significant pathologic and one significant mass-balance shift were observed in April. Both shifts were recorded by the analysis of $\delta^{13} \mathrm{C}$ for the L. minimus-C. edule system, when the parasite prevalence and infestation load were the highest. In the case of the pathologic shift, the ${ }^{13} \mathrm{C}$ depletion of the digestive gland and gonad (Fig. 1e) may result from cockle metabolism disturbances by the parasite and from an increase of biochemical compounds like lipids (Lauckner 1983) that are known to be depleted in ${ }^{13} \mathrm{C}$ (DeNiro \& Epstein 1977). However, even if significant, the pathologic shift in $\delta^{13} \mathrm{C}$ between healthy and parasitized DGG $(0.23 \%)$ was very close to the analytical uncertainty of $0.14 \%$. At the same time, i.e. in April, a significant difference of $0.5 \%$ in $\delta^{13} \mathrm{C}$ values was recorded between the $L$. minimus parasite and healthy cockles. The recorded ${ }^{13} \mathrm{C}$ depletion in the parasite (Fig. 1e), combined with a large infestation load (Fig. 1f) and a shift in the DGG $\delta^{13} \mathrm{C}$ of cockles (Fig. 1d), was large enough to significantly modify the $\delta^{13} \mathrm{C}$ signature of the entire parasite-host system (Fig.1e). This difference of $0.15 \%$ on average between healthy cockles and parasite-host systems is, however, similar to the inter-individual SD $(0.16 \%)$ and to the analytical uncertainty $(0.14 \%)$. Moreover, this difference is low in comparison to other sources of variation that are known to occur both spatially and seasonally in cockle populations. For instance, a change of $+1.9 \%$ was reported between March and December in cockle isotopic signature (Sauriau \& Kang 2000) and a difference of -1\%o was observed between cockle individuals from 2 stations in the Molenplaat mudflat, Netherlands (Herman et al. 2000). Differences in isotopic signatures between organs are also reported in bivalves, with lipid-rich organs such as gonads and digestive glands much more depleted in ${ }^{13} \mathrm{C}$ than muscles (Stephenson \& Lyon 1982, Lorrain et al. 2002, Malet et al. 2007). Differences of +1 to $+1.5 \%$ o found in the present study between the $\delta^{13} \mathrm{C}$ values of muscle and gonads of cockle (Figs. $1 \& 2$ ) and dogwhelks (Fig. 3) are similar to that reported for other molluscs; for example, $+1.3 \%$ for Chione stuchburyi (Stephenson \& Lyon 1982), +2.9\% for Pecten maximus (Lorrain et al. 2002) and 0.5 to $1.5 \%$ for Crassostrea gigas (Malet et al. 2007). Similarly to our results on both cockles and dogwhelks, stable nitrogen signa- tures in mollusc muscle are also reported to be more enriched compared to gonads and digestive glands (Lorrain et al. 2002, Malet et al. 2007).

Although the stable $\mathrm{C}$ isotopic signature of the parasite Monorchis parvus was different from that of the healthy cockle individuals in February (Fig. 2b), this difference was associated with a low parasite infestation load, hence the mass-balance shift on the whole parasite-host system was undetectable. Assuming that the isotopic signature of parasites measured in winter would still be valid when the infestation is larger, a simple mass-balance calculation can give the minimum parasite infestation load needed to induce a 'significant' shift in $\delta^{15} \mathrm{~N}$ and/or $\delta^{13} \mathrm{C}$ of the studied parasite-cockle system(s). We consider here that the shift would be 'significant' when larger than $0.2 \%$. The calculated minimum infestation loads are 79 and $52 \%$ for $\delta^{15} \mathrm{~N}$ and $\delta^{13} \mathrm{C}$ of the M.-Cerastoderma edule system, respectively, and $35 \%$ for $\delta^{13} \mathrm{C}$ of the Labratrema minimus-C. edule system. Much higher infestation loads than that recorded for the present studied parasitehost systems (see Table 1) have been documented only 3 times: 18 to $34 \%$ for a Labratrema minimus-C. edule system (Baudrimont \& de Montaudouin 2007); 16 to $51 \%$ for a trematode-snail system (Bernot \& Lamberti 2008); and 14 to $39 \%$ for another trematode-snail system (Hechinger et al. 2008) . However, in the case of the L. minimus-C. edule system, the maximum infestation loads remain below the threshold values needed to induce a significant mass-balance shift in $\delta^{15} \mathrm{~N}$ and $\delta^{13} \mathrm{C}$ values.

Overall, digenean trematode parasitism induced little or no pathologic or mass-balance shifts in cockle and dogwhelk stable isotope signatures. In contrast, Doi et al. (2008) reported an increase of $1.4 \%$ in $\delta^{15} \mathrm{~N}$ from healthy to parasitized hepatopancreas of freshwater gastropod Lymnaea stagnalis infested by the trematode Plagiorchis sp. Since the trematode parasite cannot be extracted from host tissues, they calculated that the contribution of the parasite to the total gastropod biomass was 1 to $3 \%$. Doi et al. (2008) also assumed that this isotopic enrichment was due to a mass-balance shift. This suggests that isotopic enrichment between hosts and parasites may be specific to each parasite-host system and/or to the levels of the metabolic relationships between parasites and their host.

\section{Host-parasite isotopic fractionation: characteriza- tion of trophic relationship}

The average trophic enrichment values of about 3 to $4 \%$ in $\delta^{15} \mathrm{~N}$ and $1 \%$ in $\delta^{13} \mathrm{C}$ between predators and their prey do not stand for the parasite-host systems 
(e.g. Focken \& Becker 1998, Yokoyama et al. 2005). Although similar enrichment values have been reported (Table 3), much higher enrichment and depletion values have been previously reported between parasite and host for both ectoparasite- and endoparasite-host systems (Iken et al. 2001, Pinnegar et al. 2001, Deudero et al. 2002, Parmentier \& Das 2004, Power \& Klein 2004, Persson et al. 2007). Accordingly, $\delta^{15} \mathrm{~N}_{\mathrm{P}}-\delta^{15} \mathrm{~N}_{\mathrm{H}}$ (P: parasite, $\mathrm{H}$ : host) ranged from -4.2 to $2.8 \%$ and $\delta^{13} \mathrm{C}_{\mathrm{P}}-\delta^{13} \mathrm{C}_{\mathrm{H}}$ from -4.1 to $-0.1 \%$ for ectoparasites. Mean values of $\delta^{15} \mathrm{~N}_{\mathrm{P}}-\delta^{15} \mathrm{~N}_{\mathrm{H}}$ ranged from -6.7 to $7.2 \%$ and $\delta^{13} \mathrm{C}_{\mathrm{P}}-\delta^{13} \mathrm{C}_{\mathrm{H}}$ from -10.1 to $3.7 \%$ for endoparasites (Table 3). Nevertheless, studies of endoparasite-host systems using stable isotopes are still scarce and, to the best of our knowledge, only one study has focussed on molluscs (Doi et al. 2008). Unfortunately, this study did not report parasite isotopic values.

Gonad is usually the most parasitized tissue (James \& Bowers 1967, Lauckner 1983) in relation to its high lipid content (Lorrain et al. 2002, Malet et al. 2007) and the higher energetic value of lipids compared to other biochemical compounds (Deslous-Paoli et al. 1988). Since sporocysts were highly interwoven within host DGG, assessment of their trophic relationships could be made by comparing their respective isotopic signatures. Feeding resources of gutless sporocysts are composed of dissolved material that may be either metabolized or not metabolized by the host. Thus, we consider that sporocysts of cockle parasites feed only on dissolved material metabolized by the host because of the parasite physiology with abbreviated metabolism and catabolism pathways (see below).

\section{Slight but systematic ${ }^{13} \mathrm{C}$ depletion of the parasite}

A ${ }^{13} \mathrm{C}$-depletion of the parasites (from -1.0 to $-0.2 \%$ ) with respect to cockle digestive gland and gonads (DGG, the most parasitized tissues) was recorded (Table 2, Figs. 1a,e \& 2a,e). However, the depletion was not significant for Labratrema minimus in January or Monorchis parvus in April. It is interesting to note that parasite $\delta^{13} \mathrm{C}$ was constant over time and was identical for both parasites with sporocysts only $(-17.9$ $\pm 0.1 \%$ ) (Fig. 4).

Isotopic shifts result from the isotopic balance between several mechanisms: assimilation by way of ingestion and metabolism, and excretion by way of feces and respiration (Olive et al. 2003). The sporocyst stage of trematode digenean parasites requires access to large amounts of energy substrates (Khayath et al. 2006). However, sporocysts would have a limited access to glucose which is in low quantity in host tissues such as DGG (Perez et al. 1994). Khayath et al. (2006) showed that sporocysts of Schistosoma mansoni used a truncated gluconeogenic pathway to produce glycerol. In addition, accumulation of organic endproducts by parasites indicates very limited or no terminal respiration (Saz 1981). Thus, sporocysts seem to use abbreviated metabolic pathways for energy production. It is likely that this is the case for energy catabolisation (Power \& Klein 2004); production of energy for the multiplication of sporocysts and the build-up of cercariae appear to be the main metabolic priority for the sporocyst stage. If most of the material ingested by digenean trematodes were used for

Table 3. Isotopic shifts for parasite-host systems in the literature. P: parasite, H: host

\begin{tabular}{|c|c|c|c|c|}
\hline Parasite-host system & Host tissue & $\begin{array}{c}\delta^{15} \mathrm{~N}_{\mathrm{P}}-\delta^{15} \mathrm{~N}_{\mathrm{H}} \\
(\%)\end{array}$ & $\begin{array}{c}\delta^{13} \mathrm{C}_{\mathrm{P}}-\delta^{13} \mathrm{C}_{\mathrm{H}} \\
(\% \text { \%) }\end{array}$ & Source \\
\hline \multicolumn{5}{|l|}{ Endoparasites } \\
\hline Trematode-mollusc & Digestive gland and gonad & -0.3 to +0.6 & -1.0 to -0.2 & Present study \\
\hline Trematode-fish & Gut & 0.0 to -2.6 & +3.7 to +0.4 & Iken et al. 2001 \\
\hline Nematode-fish & Gut & -2.3 to -1.6 & +3.0 to +3.3 & Iken et al. 2001 \\
\hline Cestode-fish & Coelomic cavity & -1.4 to -4.4 & 0.0 to +0.6 & Power \& Klein 2004 \\
\hline Cestode-fish & Pyloric caeca & -2.5 & +1.6 & Persson et al. 2007 \\
\hline Endoparasite-fish & Liver, peritoneal cavity & -2.4 to -1.4 & -0.1 to +2.0 & Pinnegar et al. 2001 \\
\hline Endoparasite-fish & $\begin{array}{l}\text { Peritoneal cavity, liver, } \\
\text { intestine stomach }\end{array}$ & -6.7 to -1.6 & -2.9 to -0.3 & Deudero et al. 2002 \\
\hline Fish-echinoderm & Coelomic cavity & +5.3 to +7.2 & -10.1 to -5.0 & Parmentier \& Das 2004 \\
\hline \multicolumn{5}{|l|}{ Ectoparasites } \\
\hline Gastropod-holoturidae & Skin & -0.2 & -0.7 & Iken et al. 2001 \\
\hline Cirripedia-decapod & Skin & -0.2 & -2.1 & Iken et al. 2001 \\
\hline Copepod-fish & Gills & +2.8 & -0.1 & Iken et al. 2001 \\
\hline Ectoparasite-fish & Skin, gills & -0.3 to -0.8 & -1.6 to -0.1 & Pinnegar et al. 2001 \\
\hline Ectoparasite-fish & Gills, peritoneal cavity & -4.2 to +1.1 & -4.1 to -0.4 & Deudero et al. 2002 \\
\hline
\end{tabular}



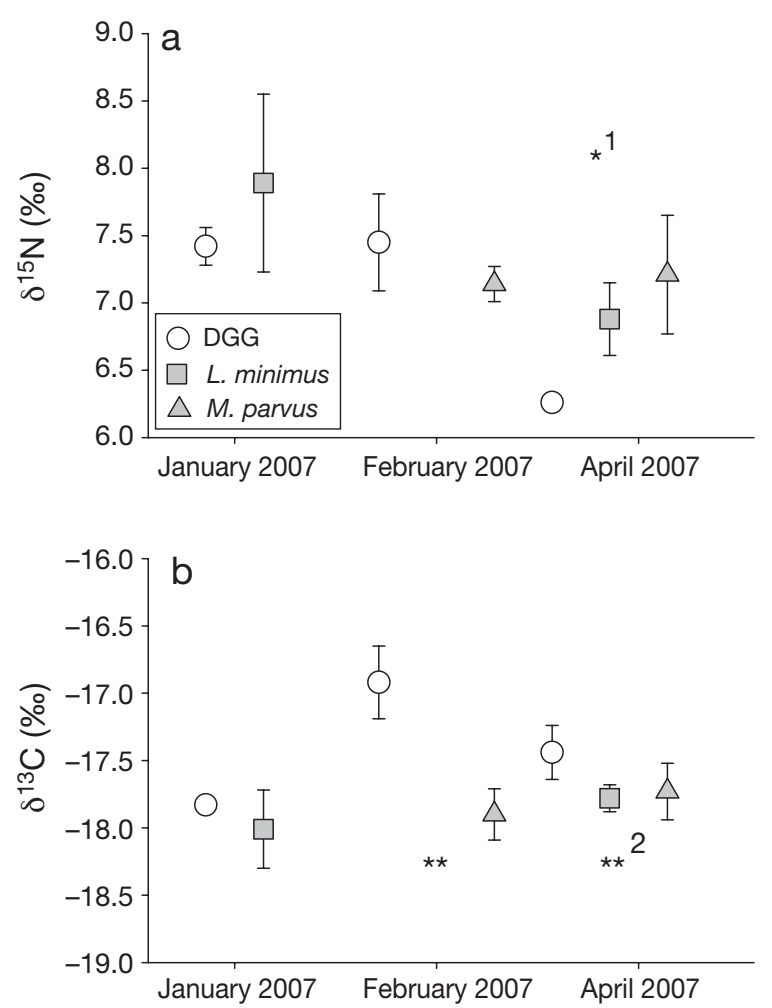

Fig. 4. Cerastoderma edule, Labratrema minimus and Monorchis parvus. $\delta^{15} \mathrm{~N}(\mathrm{a})$ and $\delta^{13} \mathrm{C}(\mathrm{b})$ of healthy cockle DGG and parasites L. minimus and M. parvus. ${ }^{*}$ : $\mathrm{p}<0.05 ;{ }^{* *}$ : $\mathrm{p}<0.01 ; 1$ : significance is for both parasite-host systems; 2 : significance is only for $L$. minimus-C. edule system. DGG: digestive gland and gonad

growth and reproduction - if almost none of the ingested material is lost through feces, excretion and respiration-then the parasite isotopic signature should be very close to that of its feeding source within the host, i.e. the parasitized organ or some of its specific compound(s). In addition, the use of abbreviated metabolic pathways for respiration and gluconeogenesis induces a very low, even undetectable, isotopic shift between the parasite and its food source.

In the present study, parasites were lightly ${ }^{13} \mathrm{C}$ depleted (from -1.0 to $-0.2 \%$ ) with respect to the DGG cockle for both parasite-host systems. As both parasite $\delta^{13} \mathrm{C}$ values are identical and constant over time, such pattern indicates that both parasites feed on the same food source. Mollusc DGG usually exhibits a high lipid content (e.g. Lorrain et al. 2002, Malet et al. 2007), and lipids are known to be ${ }^{13} \mathrm{C}$ depleted (DeNiro \& Epstein 1977, Lorrain et al. 2002, Bodin et al. 2007). This explains the fact that DGG $\delta^{13} \mathrm{C}$ in cockles is systematically the lowest compared to that of the other tissues. Parasite $\delta^{13} \mathrm{C}$ values are very close to DGG $\delta^{13} \mathrm{C}$, suggesting that parasites mostly feed on this tissue. How- ever, parasites were still ${ }^{13} \mathrm{C}$ depleted compared to DGG. Assuming that no fractionation could arise because of ${ }^{13} \mathrm{C}$ loss due to feces, excretion or respiration, this indicates that parasite preferentially feeds on ${ }^{13} \mathrm{C}$-depleted compounds of the DGG. Digenean trematodes may accumulate a higher fraction of lipid than their feeding source (DGG). This conclusion is partly strengthened by the fact that parasites exhibit lower or similar C:N ratios compared to healthy DGG (data not shown). However, only lipid analysis would corroborate such a hypothesis.

Considering the classical predator-prey relationship, excretion and respiration lead to a loss of light isotopes and thus to an accumulation of heavy isotopes within the prey (e.g. Checkley \& Entzeroth 1985). This mechanism explains the isotopic fractionation between prey and predator. In the present study, slight ${ }^{13} \mathrm{C}$ depletion is observed between parasite and host. This depletion indicates that, if excretion and/or respiration coexist with the use of a light food source, the balance favours the use of this light food source (e.g. lipids) in contrast to the loss of ${ }^{12} \mathrm{C}$, and thus indicates that excretion and respiration should be low and their influence on DGG $\delta^{13} \mathrm{C}$ may be negligible.

\section{Slight or no ${ }^{15} \mathrm{~N}$ trophic enrichment}

Regarding Labratrema minimus, ${ }^{15} \mathrm{~N}$ trophic enrichment of parasites with respect to cockle DGG was constant over time $(0.5 \%$ in January and $0.6 \%$ in April). Nevertheless, this trophic enrichment was only significant for April. L. minimus' $\delta^{15} \mathrm{~N}$ value decreased from $7.9 \%$ in January to $6.9 \%$ in April (Fig. 4). Similarly, no trophic enrichment ( $-0.3 \%$ in February) or a slight ${ }^{15} \mathrm{~N}$ trophic enrichment of $1.0 \%$ was recorded for Monorchis parvus with respect to cockle DGG. However, $\delta^{15} \mathrm{~N}$ values of $M$. parvus were constant over time $\left(7.2 \%\right.$ o). Such slight ${ }^{15} \mathrm{~N}$ trophic enrichments are in agreement with some results reported in the literature regarding endoparasite-host systems (e.g. Iken et al. 2001). However, they do not agree with other studies in which parasites can be either largely depleted or enriched in ${ }^{15} \mathrm{~N}$ with respect to their host (e.g. Deudero et al. 2002, Parmentier \& Das 2004, our Table 3).

In organisms, carbon is present as lipids, glucides and proteins, whereas nitrogen is mainly present as proteins. Hence, ${ }^{15} \mathrm{~N}$ trophic enrichment is generally recognized to be the result of the breakdown of proteins to more simple amino acids together with the loss of ${ }^{14} \mathrm{~N}$-enriched excretory products. As some endoparasites have only limited capabilities for amino acid synthesis, they sustain their metabolic requirements by actively absorbing amino acids from 
their host (e.g. Deudero et al. 2002). The observation that Labratrema minimus exhibits slight or no ${ }^{15} \mathrm{~N}$ trophic enrichment with respect to cockle DGG is in line with these hypotheses. This indicates that either Labratrema minimus can feed on a specific compound(s) that exhibit(s) different $\delta^{15} \mathrm{~N}$ value(s) than the entire DGG (assuming no loss of N-compounds) or that there is a light fractionation process between DGG and the parasite due to a small loss of ${ }^{14} \mathrm{~N}$ enriched material (e.g. by excretion or tegument diffusion). None of these 2 processes can be dismissed nor favoured using the present dataset. Only the analysis of the amino acid composition and $\delta^{15} \mathrm{~N}$ of both host DGG and parasite body would elucidate which process explains the $\delta^{15} \mathrm{~N}$ difference.

In contrast, Monorchis parvus exhibited no systematic fractionation with respect to cockle DGG, but did show a constant $\delta^{15} \mathrm{~N}$ over time. This may be due to the consumption of specific DGG amino acids with constant $\delta^{15} \mathrm{~N}$ over time (at least at the time scale of the present study). This may be also due to the biochemical dynamics of the parasite relative to the cockle growth and reproductive cycles, which may induce a different behaviour regarding $\delta^{15} \mathrm{~N}$. Large modifications in the biochemical composition of cockles are expected to occur during the sampling period (January to April) due to growth and reproduction (Newell \& Bayne 1980, Navarro et al. 1989), especially in the DGG, which is the largest tissue component of cockles. These modifications are related to the start of the gametogenesis and seasonal changes in food availability. Also, the increase in parasite biomass relative to the cockle biomass is huge between February and April (from 5 to $18 \%$ ). Low or no trophic enrichment between parasites and hosts could also be linked to the excretion form of nitrogen. Indeed, invertebrate organisms excrete nitrogen as ammonia, which requires less synthesis steps than the excretion of urea (Vanderklift \& Ponsard 2003). Nevertheless, the cause of the differences in $\delta^{15} \mathrm{~N}$ dynamics between Labratrema minimus and $M$. parvus with respect to Cerastoderma edule remains unknown. Analysis of the amino acid composition and $\delta^{15} \mathrm{~N}$ of the DGG and the parasite could better our understanding of what process or processes control the $\delta^{15} \mathrm{~N}$ differences between these parasites and their cockle hosts.

\section{CONCLUSIONS}

One pathologic and one mass-balance shift were observed among the 4 parasite-host systems studied. Both occurred in the case of the digenean trematode Labratrema minimus (sporocysts only)-bivalve mollusc Cerastoderma edule system when the parasite infestation load was high. Although significant, the recorded $\delta^{13} \mathrm{C}$ shift was low compared to usual analytical uncertainty and to seasonal or spatial variability. Overall, measurements indicated that digenean trematode parasitism induced low or no shifts in cockle and dogwhelk isotopic signatures. This supports the conclusion that both $C$. edule and Nassarius reticulatus can be analyzed in toto for determining their isotopic signatures in the context of food web studies without checking their parasite infestation. If one expects an isotopic shift due to a large parasite infestation of $C$. edule, we recommend its foot to be analysed since the isotopic signature of this organ is the closest to, and is not significantly different from, the isotopic signature of the entire individual. The comparison between parasite (L. minimus and Monorchis parvus) and C. edule DGG isotopic signatures exhibited a light but systematic ${ }^{13} \mathrm{C}$-depletion and no fractionation or a low ${ }^{15} \mathrm{~N}$ enrichment in the parasites. This indicates that parasites mainly feed on DGG with a possible slight preference for lipids. This also suggests the use of abbreviated metabolic pathways with light fractionation processes by the endoparasite and/or low loss of metabolic material through excretion, tegument diffusion and respiration.

Acknowledgements. We thank Captain F. Prince of the RV 'Planula IV' (INSU/CNRS), P. Lebleu and M. Leconte for their helpful assistance during fieldwork and K. Charlier for EAIRMS assistance when I.B. was not available.

\section{LITERATURE CITED}

Bachelet G, Simon-Bouet B, Desclaux C, Garcia-Meunier P and others (2004) Invasion of the eastern Bay of Biscay by the nassariid gastropod Cyclope neritae: origin and effects on resident fauna. Mar Ecol Prog Ser 276:147-159

Baudrimont M, de Montaudouin X (2007) Evidence of an altered protective effect of metallothioneins after cadmium exposure in the digenean parasite-infected cockle (Cerastoderma edule). Parasitology 134:237-245

Bernot RJ, Lamberti GA (2008) Indirect effects of a parasite on a benthic community: an experiment with trematodes, snails and periphyton. Freshw Biol 53:322-329

> Bodin N, Le Loc'h F, Hily C (2007) Effect of lipid removal on carbon and nitrogen stable isotope ratios in crustacean tissues. J Exp Mar Biol Ecol 341:168-175

> Checkley DM, Entzeroth LC (1985) Elemental and isotopic fractionation of carbon and nitrogen by marine, planktonic copepods and implications to the marine nitrogen cycle. J Plankton Res 7:553-568

Combes C (1995) Interactions durables: écologie et évolution du parasitisme. Masson, Paris

de Montaudouin X, Thieltges D, Gam M, Krakau M and others (in press) Digenean trematode species in the cockle Cerastoderma edule: identification key and distribution along the northeast Atlantic shoreline. J Mar Biol Assoc UK

Deltreil JP, His E (1970) Sur la présence d'une cercaire de trématode chez Cardium edule L. dans le Bassin d'Arcachon. Rev Trav Inst Pech Marit 34:1225-1232 
DeNiro MJ, Epstein S (1977) Mechanism of isotope carbon fractionation associated with lipid synthesis. Science 197: 261-263

> DeNiro MJ, Epstein S (1978) Influence of diet on the distribution of carbon isotopes in animals. Geochim Cosmochim Acta 42:495-506

> DeNiro MJ, Epstein S (1981) Influence of diet on the distribution of nitrogen isotopes in animals. Geochim Cosmochim Acta 45:341-351

Desclaux C, de Montaudouin X, Bachelet G (2002) Cockle emergence at the sediment surface: 'favourization' mechanism by digenean parasites? Dis Aquat Org 52:137-149

Deslous-Paoli JM, Héral M, Jousset M, Boromthanarat S, Goulletquer P, Sauriau PG (1988) Total lipid content and lipid energetic values of bivalve molluscs. Comp Biochem Physiol B 89:51-53

Deudero S, Pinnegar JK, Polunin NVC (2002) Insights into fish host-parasite trophic relationships revealed by stable isotope analysis. Dis Aquat Org 52:77-86

> Doi H, Yurlova NI, Vodyanitskaya SN, Kikuchi E, Shikano S, Yadrenkina EN, Zuykova EI (2008) Parasite-induced changes in nitrogen isotope signatures of host tissues. J Parasitol 94:292-295

Fantle MS, Dittel AI, Schwalm SM, Epifanio CE, Fogel ML (1999) A food web analysis of the juvenile blue crab, Callinectes sapidus, using stable isotopes in whole animals and individual amino acids. Oecologia 120:416-426

Focken U, Becker K (1998) Metabolic fractionation of stable carbon isotopes: implication of different proximate compositions for studies of the aquatic food webs using $\delta^{13} \mathrm{C}$ data. Oecologia 115:337-343

Gannes LZ, O'Brien DM, Martinez del Rio C (1997) Stable isotopes in animal ecology: assumptions, caveats, and a call for more laboratory experiments. Ecology 78:1271-1276

Hechinger RF, Lafferty KD, Mancini FT III, Warner RR, Kuris AM (2008) How large is the hand in the puppet? Ecological and evolutionary factors affecting body mass of 15 trematode parasitic castrators in their snail host. Evol Ecol. doi:10.1007/s10682-008-9262-4

Herman PMJ, Middelburg JJ, Widdows J, Lucas $\mathrm{CH}$, Heip CHR (2000) Stable isotopes as trophic tracers: combining field sampling and manipulative labelling of food resources for macrobenthos. Mar Ecol Prog Ser 204:79-92

Hobson KA, Welch HE (1992) Determination of trophic relationships within a high Artic marine food web using $\delta^{13} \mathrm{C}$ and $\delta^{15} \mathrm{~N}$ analysis. Mar Ecol Prog Ser 84:9-18

Iken K, Brey T, Wand U, Voigt J, Junghans P (2001) Food web structure of the benthic community at the Porcupine Abyssal Plain (NE Atlantic): a stable isotope analysis. Prog Oceanogr 50:383-405

James BL, Bowers EA (1967) Reproduction in the daughter sporocyst of Cercaria bucephalopsis haimeana (LacazeDuthiers, 1854) (Bucephalidae) and Cercaria dichotoma Lebour, 1911 (non Müller) (Gymnophallidae). Parasitology 57:607-625

> Jensen KT, Mouritsen KN (1992) Mass mortality in two common soft-bottom invertebrates, Hydrobia ulvae and Corophium volutator: the possible role of trematodes. Helgol Meersunters 46:329-339

Khayath N, Mithieux G, Zitoun C, Coustau C, Vicogne J, Tielens AG, Dissous C (2006) Glyceroneogenesis: an unexpected metabolic pathway for glutamine in Schistosoma mansoni sporocysts. Mol Biochem Parasitol 147:145-153

Lauckner G (1983) Diseases of Mollusca: Bivalvia. In: Kinne O (ed) Diseases of marine animals. Vol II. Introduction, Bivalvia to Scaphopoda. Biologische Anstalt Helgoland, Hamburg, p 477-961
Lauckner G (1984) Impact of trematode parasitism on the fauna of a North Sea tidal flat. Helgol Meersunters 37: 185-199

- Lorrain A, Paulet YM, Chauvaud L, Savoye N, Donval A, Saout C (2002) Differential $\delta^{13} \mathrm{C}$ and $\delta^{15} \mathrm{~N}$ signatures among scallop tissues: implications for ecology and physiology. J Exp Mar Biol Ecol 275:47-61

Maillard C (1976) Distomatoses de poisons en milieu lagunaire. PhD thesis, University Sciences and Techniques du Languedoc

Malet N, Sauriau PG, Faury N, Soletchnik P, Guillou G (2007) Effect of seasonal variation in trophic conditions and the gametogenic cycle on $\delta^{13} \mathrm{C}$ and $\delta^{15} \mathrm{~N}$ levels of diploid and triploid Pacific oysters Crassostrea gigas. Mar Ecol Prog Ser 346:203-217

> Navarro E, Iglesias JIP, Larrañaga A (1989) Interannual variation in the reproductive cycle and biochemical composition of the cockle Cerastoderma edule from Mundaca Estuary Biscay, North Spain). Mar Biol 101:503-511

> Newell RIE, Bayne BL (1980) Seasonal changes in the physiology, reproductive condition and carbohydrate content of the cockle Cardium (=Cerastoderma) edule (Bivalvia: Cardiidae). Mar Biol 56:11-19

Olive PJW, Pinnegar JK, Polunin NVC, Richards G, Welch R (2003) Isotope trophic-step fractionation: a dynamic equilibrium model. J Anim Ecol 72:608-617

> Pakhomov EA, McClelland JW, Bernard K, Kaehler S, Montoya JP (2004) Spatial and temporal shifts in stable isotope values of the bottom-dwelling shrimp Nauticaris marionis at the sub-Antarctic archipelago. Mar Biol 144: $317-325$

> Parmentier E, Das K (2004) Commensal vs. parasitic relationship between Carapini fish and their hosts: some further insight through $\delta^{13} \mathrm{C}$ and $\delta^{15} \mathrm{~N}$ measurements. J Exp Mar Biol Ecol 310:47-58

> Paulet YM, Lorrain A, Richard J, Pouvreau S (2006) Experimental shift in diet $\delta^{13} \mathrm{C}$ : a potential tool for ecophysiological studies in marine bivalves. Org Geochem 37 : 1359-1370

Perez MK, Fried B, Sherma J (1994) High performance thinlayer chromatographic analysis of sugars in Biomphalaria glabrata (Gastropoda) infected with Echinostoma caproni (Trematoda). J Parasitol 80:336-338

> Persson ME, Larsson P, Stenroth P (2007) Fractionation of $\delta^{15} \mathrm{~N}$ and $\delta^{13} \mathrm{C}$ for Atlantic salmon and its intestinal cestode Eubothrium crassum. J Fish Biol 71:441-452

Peterson BJ, Fry B (1987) Stable isotopes in ecosystem studies. Annu Rev Ecol Syst 18:293-320

Pinnegar JK, Campbell N, Polunin NVC (2001) Unusual stable isotope fractionation patterns observed for fish host-parasite trophic relationships. J Fish Biol 59:494-503

Post DM (2002) Using stable isotopes to estimate trophic position: models, methods and assumptions. Ecology 83: 703-718

> Power M, Klein GM (2004) Fish host-cestode parasite stable isotope enrichment patterns in marine, estuarine and freshwater fishes from northern Canada. Isot Environ Health Stud 40:257-266

> Rau GH, Hopkins TL, Torres JJ (1991) ${ }^{15} \mathrm{~N} /{ }^{14} \mathrm{~N}$ and ${ }^{13} \mathrm{C} /{ }^{12} \mathrm{C}$ in Weddell Sea invertebrates: implications for feeding diversity. Mar Ecol Prog Ser 77:1-6

Russell-Pinto F, Gonçalves JF, Bowers E (2006) Digenean larvae parasitizing Cerastoderma edule (Bivalvia) and Nassarius reticulatus (Gastropoda) from Ria de Aveiro, Portugal. J Parasitol 92:319-332

> Sauriau PG, Kang CK (2000) Stable isotope evidence of benthic microalgae-based growth and secondary production in the 
suspension feeder Cerastoderma edule (Mollusca, Bivalvia) in the Marennes-Oléron Bay. Hydrobiologia 440:317-329

Saz HJ (1981) Energy generation in parasitic helminths. In: Slutsky GM (ed) The biochemistry of parasites. Pergamon Press, Oxford, p 179-189

Stephenson RL, Lyon GL (1982) Carbon-13 depletion in an estuarine bivalve: detection of marine and terrestrial food sources. Oecologia 55:110-113

Thieltges DW (2006) Parasite induced summer mortality in the cockle Cerastoderma edule by the trematode Gymnophallus choledochus. Hydrobiologia 559:455-461

Thomas F, Cezilly F, Meeüs TD, Crivelli A, Renaud F (1997)

Editorial responsibility: Sven Klimpel,

Düsseldorf, Germany
Parasitism and ecology of wetlands: a review. Estuaries 20:646-654

Vander Zanden MJ, Rasmussen JB (2001) Variation in $\delta^{15} \mathrm{~N}$ and $\delta^{13} \mathrm{C}$ trophic fractionation: implications for aquatic food web studies. Limnol Oceanogr 46:2061-2066

Vanderklift MA, Ponsard S (2003) Sources of variation in consumer-diet $\delta^{15} \mathrm{~N}$ enrichment: a meta-analysis. Oecologia 136:169-182

Yokoyama H, Tamaki A, Harada K, Shimoda K, Koyama K, Ishihi Y (2005) Variability of diet-tissue isotopic fractionation in estuarine macrobenthos. Mar Ecol Prog Ser 296: $115-128$

Submitted: June 12, 2008; Accepted: December 10, 2008 Proofs received from author(s): February 16, 2009 